ISSN : 2615-1995, E-ISSN : 2615-0654

J. Madani., Vol. 4, No. 1, Maret 2021 (34 - 44)

(C)2018 Lembaga Kajian Demokrasi

\title{
Analisis Evaluasi Keberhasilan Inovasi Sistem Aplikasi By Data Pada UKM Minuman Kekinian di Kota Tangerang Selatan (Studi Kasus Minuman “Ngombe”)
}

\author{
Rahmayanti Tumanggor \\ Fakultas Ekonomi, Universitas Pamulang \\ dosen02223@unpam.ac.id \\ Wiyanto \\ Fakultas Ekonomi, Universitas Pamulang \\ dosen01840@unpam.ac.id
}

\begin{abstract}
Abstrak
Penelitian ini bertujuan untukmenganalisis evaluasi keberhasilan inovasi sistem aplikasi by data pada UKM minuman kekinian (Ngombe) di Kota Tangerang Selatan. Juga untuk mengetahui pengaruh dan manfaat penggunaan sistem aplikasi by data terhadap peningkatan penjualan minuman kekinian. Bagaimana sistem aplikasi "by data" dapat membantu para pelaku usaha minuman kekinian dalam mengembangkan usahanya sehingga tercapai penjualan yang cukup signifikan dan memberi keuntungan ekonomis Metode penelitian yang digunakan adalah kualitatif yang bersifat analisis deskriptif. Teknik pengumpulan data adalah observasi, wawancara, dokumentasi, FGD dan triangulasi. Metode analisis data bersifat induktif, dikembangkan menjadi hipotesis, mengorganisasikan data ke dalam kategori, menjabarkan ke dalam unit-unit, melakukan sintesa, menyusun ke dalam pola, sehingga mendapatkan satu kesimpulan. Hasil penelitian berdasarkan analisis SWOT perhitunganan EFI dan EFE nilai skor tertimbang EFI sebesar 3.65, artinya usaha yang dikembangkan memiliki posisi kekuatan internal baik. Sedangkan skor tertimbang EFE diperoleh nilai 3,30 mengindikasikan bahwa faktor eksternal cukup mendukung usaha yang dilakukan. Dengan menggunakan matrik SPACE, usaha Minuman Ngombe berada pada posisi kuadran III yaitu kondisi agresif. Kesimpulannya bahwa minuman kekinian yang menggunakan sistem aplikasi 'by data' memberikan kemudahan dalam penjualan, juga memberikan keuntungan yang signifikan bagi pemiliknya.
\end{abstract}

Kata Kunci : Produk, Profit, Inovasi, Sistem Aplikasi by data

\section{Abstract}

This aims of the study is to analyze the evaluation of innovation successful of by data application system at modern beverage MSMEs (Ngombe) in South Tangerang City. Also to find out influence and benefits of using by data application system to increase sales of modern beverages. Also to know how the "by data" application system can help modern beverage business entrepreneurs to achieve significant sales and to provide economic benefits. The method used in this study was descriptive analysis of qualitative method. The analysis technique uses observation, interview, documentation, forum group discussion and triangulation. 
The analysis data method was inductive that based on the accumulation of data, then developed in to hypothesis by organize the data in to category, outline into units, do synthesis, compile in to the pattern to get the conclusion. Based on the SWOT analysis, the EFI and EFE calculations obtained the EFI score of 3.65, meaning that the business has a good internal strength position. While the EFE score is 3.30 indicating that external factors are sufficient to support the business. By using the SPACE matrix, Ngombe is in quadrant III, which is an aggressive condition. The conclusion is that implementation of by data application system gives ease in the service to consumers and provides significant advantage to the owner.

Keywords : Product, Profit, Innovation, "by data” Application System

\section{PENDAHULUAN}

Perubahan dan pegesaran teknologi menuntut setiap perusahaan dapat berbenah dalam menghadapi persaingan yang semakin kompetitif. Untuk dapat memenangkan persaingan dalam dunia usaha, perusahaan harus mampu menciptakan inovasi, yakni perubahan yang terjadi dalam suatu perusahaan dan merupakan salah satu cara untuk mengembangkan sebuah perusahaan menuju arah perubahan yang lebih baik. Perubahan sangatlah dibutuhkan agar perusahaan dapat menjaga eksistensinya, serta meningkatkan pendapatan perusahaan.

Inovasi bertujuan untuk menyempurnakan atau meningkatkan fungsi dari pemanfaatan suatu produk atau sumber daya sehingga manusia mendapatkan manfaat yang lebih dari inovasi tersebut. Fenomena yang dapat dijadikan contoh inovasi produk atau jasa adalah para pelaku usaha UMKM terutama usaha di bidang makanan dan minuman. Begitu maraknya bermunculan usaha di bidang ini, menunjukkan semakin baiknya iklim ekonomi mendukung tumbuh kembangnya UMKM.

Seiring dengan semakin majunya teknologi dan perkembangan aplikasi IT, juga dimanfaatkan sebagai sarana pemasaran dan promosi bidang usaha. Salah satu yang menjadi incaran dan daya tarik para pelaku usaha UMKM adalah bidang usaha minuman kekinian; sebagai salah satu minuman kegemaran kaum milenial yang sangat menyukai hal-hal yang bersifat praktis, kreatif, dan inovatif,

Perkembangan dunia usaha minuman kekinian ini, menggeliat bukan hanya di kota-kota besar, namun juga menjangkau hingga di tingkat Kota/ Kabupaten, bahkan sampai di wilayah Kota Tangerang Selatan. Begitu banyak muncul usaha minuman kekinian di wilayah Kota Tangerang Selatan, diantaranya yang sedang tren dengan merk "HAUS", sangat digemari oleh kaum milenial.
Perjalanan iklim UMKM di wilayah Kota Tangerang Selatan menampakkan perkembangan dan kemajuannya. Hal ini seiring dengan adanya penghargaan yang diterima oleh Kota Tangerang Selatan sebagai kota terbaik untuk iklim ekonomi Usaha Mikro Kecil Menengah (UMKM) melalui Penghargaan Natamukti Nindya, yang diberikan Menteri Koperasi dan Usaha Kecil dan Menengah Indonesia pada 28 November 2017.

Sejak Presiden Jokowi menggiatkan Usaha Mikro Kecil Menengah (UMKM), bermunculan para pelaku usaha yang bersemangat memulai usaha, bahkan mengembangkan usaha yang sudah ada. Jenis usaha yang cukup mendapat perhatian adalah bidang kuliner, baik makanan atau minuman. Seiring dengan semakin majunya teknologi dan perkembangan aplikasi IT, juga dimanfaatkan sebagai sarana pemasaran dan promosi bidang usaha. Salah satu yang menjadi incaran dan daya tarik para pelaku usaha UMKM adalah bidang usaha minuman kekinian; sebagai salah satu minuman kegemaran kaum milenial yang sangat menyukai hal-hal yang bersifat praktis, kreatif, dan inovatif. Fenomena yang menarik adalah bahwa usaha sejenis ini banyak dijalankan oleh kaum milenial; yang akan dibahas dalam penelitian ini, yakni salah satu UMKM yang bergerak di bidang minuman kekinian, dengan merk "NGOMBE".

Diawali pada tahun 2016, Joko sebagai pemilik melakukan franchise dengan produk bermerk "Rock\&Roll; berlokasi di jalan Viktor BSD. Berjalannya waktu, pemilik melepaskan ikatan franchise nya dengan "Rock\&Roll, mengingat banyaknya aturan yang mengikat, sehingga usaha franchise ini tidak bisa berkembang. Kemudian sang pemilik berpikir untuk mencari jalan membuka usaha sendiri; dengan membeli langsung semua bahan baku dan perlengkapan yang digunakan dalam proses pembuatan minuman, melalui distributor Jakarta Bubble 
Drink yang sudah berstandar BPOM dan berlabel halal MUI.

Usaha minuman ini diberi merk "Sunset", masih berlokasi di Jalan Viktor BSD. Mulai dari proses pembelian bahan baku, perlengkapan, pemasaran dan penjualan dilakukan oleh manajemen sendiri, belajar dari pengalaman kegagalan ketika usaha franchise. Namun masih ada juga kendala yang dihadapi, yakni melakukan pengawasan terhadap operasional penjualan yang dilakukan oleh karyawan. Hal ini yang membuat munculnya ide untuk bagaimana bisa melakukan pengawasan penjualan langsung oleh pemilik dengan menggunakan teknologi berbasis IT. Aplikasi ini dinamakan "sistem by data".

Keuntungan yang didapat dengan menggunakan sistem ini yaitu pengontrolan penjualan dapat dilaukan secara langsung melalui aplikasi. Kemudian keuntungan secara ekonomis, mendapatkan promosi gratis melalui sosial media Instagram, Facebook, Go Food, dan Grab Food. Selanjutnya lebih praktis, efisien waktu, dan memudahkan karyawan mengingat pesanan sesuai urutan pesanan.

Terdapat juga risiko menggunakan sistem ini, ketika konsumen membatalkan pesanan, tidak dapat diralat karena sudah masuk ke dalam sistem, dan tidak bisa diubah pesanannya. Melihat adanya kemajuan yang didapat dari usaha minuman "Sunset" ini, kemudian terpikir untuk melanjutkan usaha serupa dengan merk lain yakni "NGOMBE".

Tetap menggunakan sistem aplikasi "by data", namun ada yang membedakan dari sisi promosi; setiap mulai pembelian pertama, konsumen diberikan kartu yang diberi stempel, kemudian jika sudah mencapai pembelian ke-lima, konsumen akan diberi gratis satu.

Penerapan system aplikasi 'by data' yang dijalankan dalam usaha ini merupakan wujud dari pengembangan usaha atau yang umum disebut dengan Inovasi usaha. Ketika ditemukan adanya masalah dan kendala dalam hal penjualan, promosi, atau peningkatan penjualan, pemilik usaha dituntut agar dapat mencari solusi yang tepat dan jitu. Inovasi bisnis adalah perubahan yang terjadi dalam suatu perusahaan dan merupakan salah satu cara untuk mengembangkan sebuah perusahaan menuju arah perubahan yang lebih baik. Inovasi bisnis menjadi sebuah keharusan bagi setiap jenis usaha antara lain: perusahaan dalam skala kecil, skala menengah dan skala besar.
Inovasi usaha bisa berupa inovasi produk, inovasi penjualan, inovasi atau strategi harga, juga inovasi promosi, Dalam hal ini, inovasi yang diterapkan adalah inovasi dalam teknologi informasi yang bermanfaat dalam hal penjualan, dan meningkatkan penjualan secara signifikan dan ekonomis.

1. Produk; produk yang pemilik pasarkan adalah jenis minuman es yang desain dan inovasi yang agak berbeda dengan yang lainnya.

2. Tempat; tempat yang pemilik jadikan pemasaran adalah wilayah indomaret karna selalu ramai keluar masuk pembeli dari Indomaret.

3. Harga; harga yang pemilik tawarkan cukup terjangkau, sesuai dengan harga yang sudah beredar di pasaran dengan kualitas minuman ukuran cup 22 oz harga Rp 10.000 dan cup kecil 16 oz Rp 6.000.

4. Promosi; promosi usaha yang pemilik lakukan yakni dengan membuat brosur, medsos melalui internet atau jejaring sosial, agar tidak hanya orang dekat saja yang mengetahui tapi orang jauhpun bisa tahu usaha kami serta Go Food dan Grab Food.

Tujuan penelitian ini adalah untuk mengetahui seberapa besar pengaruh dan manfaat penggunaan dan penerapan sistem aplikasi 'by data' terhadap peningkatan penjualan minuman kekinian. Pentingnya melakukan penelitian ini yakni bagaimana sistem aplikasi 'by data' dapat membantu para pelaku usaha minuman kekinian dalam mengembangkan usahanya sehingga tercapai penjualan yang cukup signifikan dan memberi keuntungan secara ekonomis.

\section{METODE}

Metode penelitian yang digunakan didalam penelitian ini adalah metode kualitatifyang bersifat analisis deskriptif. Karena permasalahan yang ditemui bersifat holistik, kompleks, dinamis dan penuh makna, sehingga peneliti harus memahami situasi sosial secara mendalam, menemukan pola, hipotesis dan teori. Instrumen penelitian yang digunakan seperti test, kuesioner, wawancara.

Penelitian ini dilaksanakan pada ruang lingkup UMKM minuman kekinian di Kota Tangerang Selatan. Subjek dan obyek penelitian adalah pelaku usaha minuman kekinian, serta karyawan yang bekerja pada usaha yang menggunakan sistem aplikasi IT 'by data' (pemilik usaha "NGOMBE"). 
Sumber data yang digunakan dalam penelitian ini terdiri atas dua jenis yaitu data primer dan data sekunder.

Data Primer terdiri dari dua sumber, yaitu:

1. Sumber utama, yaitu diperoleh secara langsung dari pemilik usaha dan karyawan yang menggunakan sistem aplikasi 'by data'.

2. Sumber pendukung, yaitu diperoleh dari pemilik usaha minuman kekiniann di sekitar Kota Tangerang Selatan, generasi muda, serta data yang diperoleh dari catatan-catatan, dokumen, foto, maupun materi tertulis lainnya dari literatur.

Dalam penelitian ini, teknik pengumpulan data berdasarkam sifatnya yang kualitatif, menjalankan langkah-langkah sebagai berikut:

\section{Observasi}

Dalam observasi ini, peneliti terlibat langsung dengan kegiatan sehari-hari objek penelitian (pemilik\&karyawan). Diawali dengan peneliti melakukan penjelajahan umum dan menyeluruh, kemudian melakukan deskripsi terhadap semua yang dilihat, didengar, dan dirasakan, lalu semua data direkam, untuk kemudian diambil kesimpulan tahap pertama.

\section{Studi Dokumentasi}

Peneliti mengumpulkan data berupa catatan, foto atau dokumen dari sumbernya langsung yakni pelaku usaha minuman kekinian, juga dari sumber-sumber literatur lainnya.

\section{Wawancara}

Peneliti menggunakan wawancara terstruktur. Peneliti telah mengetahui informasi yang akan diprroleh; telah menyiapkan instrument penelitian berupa pertanyaan-pertanyaan tertulis yang alternative jawabnnya pun telah disiapkan.

\section{FGD (Focus Group Discussion)}

FGD adalah salah satu teknik pengumpulan data yang terarah dengan membuka forum diskusi melibatkan para peserta diskusi untuk memberikan persepsi, sikap, serta pengalaman yang dimiliki yang bertujuan untuk memudahkan peneliti dalam mengumpulkan dan melengkapi serta menganalisa data dalam penetian. FGD sebagai sebuah upaya sistematis dalam pengumpulan data dan informasi menggunakan tiga kata kunci: a. Diskusi - bukan wawancara atau obrolan

b. Kelompok - bukan individual

c. Terfokus - bukan bebas

Topik permasalahan yang dibahas dalam FGD harus spesifik karena informasi dan tujuannya sudah jelas; tetapi fokus kedalaman informasi yang didapat di dalam FGD tidak dapat digeneralisir. Manfaat dari FGD ini, peneliti dapat mengetahui persepsi, motivasi, argumentasi atau dasar dari pendapat seseorang atau kelompok. Namun demikian FGD tidak bisa dijadikan pengambilan kesimpulan dari hasil penelitian; hanya ditambahkan sebagai datapendukung lain dalam melakukan survei.

\section{Tahapan Penelitian}

Berdasarkan pada desain penelitian yang tertera diatas, tahapan Penelitian didalam penelitian ini terbagi menjadi 2 tahapan yaitu:

- Tahapan Perencanaan Penelitian

- Tahapan ini mencakup studi awal penelitian, merumuskan masalah, merancang desain penelitian, telah studi literature.

- Tahapan Pelakasanaan Penelitian

- Tahapan ini mencakup pengumpulan data dan pengolahan dan analisis data, dalam penelitian ini menggunakan analisis SWOT.

\section{HASIL}

Berdasarkan kajian pustaka yang peneliti dapat, dalam penelitian mengenai usaha Minuman "NGOMBE", berikut hasil yang didapat:

1. Usaha minuman "NGOMBE" masuk ke dalam kategori inovasi, sesuai dari penjelasan definisi inovasi yakni sebuah ide, gagasan, praktek ataupin objek/benda yang disadari dan diterima yang sebagai suatu hal yang baru oleh seseorang ataupun kelompok untuk diadopsi. Berdasarkan pengalaman perjalanan usaha, NGOMBE mengusung ide inovasi, dengan mencoba menciptakan produk dan layanan jasa yang tidak sama dengan usaha yang sejenis.

2. Sesuai dengan indikator Inovasi, bahwa produk minuman NGOMBE memberikan nilai tambah bagi pemilik usaha dari segi Inovasi produk dan layanan bagi konsumen, karena menggunakan sistem aplikasi by data, jika dibanding produk sejenis (keunggulan produk) sehingga dapat menjadikan perusahaan memiliki keunggulan dibandingkan dengan pesaingnya. 
3. Menurut ciri-ciri inovasi, bahwa minuman NGOMBE memiliki unsur kebaruan dalam hal layanan konsumen dan inovasi yang dilakukan sudah melalui program yang terencana untuk tujuan kepentingan perusahan.

4. Berdasarkan atribut inovasi, minuman NGOMBE memiliki l\#kemungkinan dicoba, karena telah melewati fase uji public dimana setiap orang atau pihak mempunyai kesempatan untuk menguji kualitas dari minuman ini.

Dari hasil observasi dan wawancara terstruktur terhadap objek penelitian, dan dari berdasarkan instumen penelitian yang Peneliti buatkan, terkait dengan $4 \mathrm{P}$ (product, price, place, promotion), didapatkan hasil bahwa penjualan minuman "NGOMBE" mengalami peningkatan dengan didukung oleh sistem aplikasi 'by data'. Berikut penjelasannya:

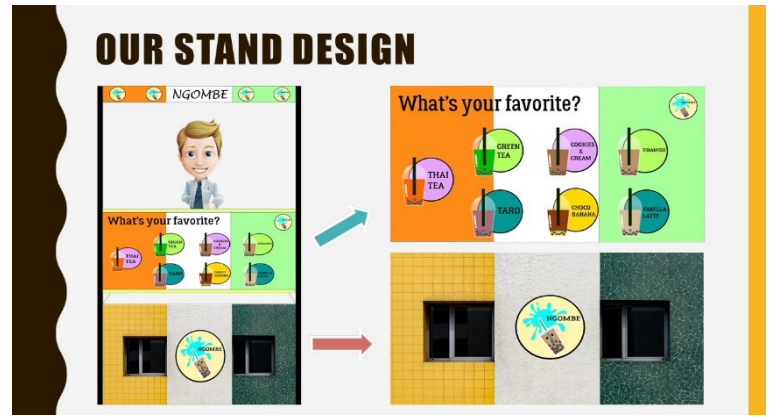

Gambar 1. Alur pemesanan minuman melalui aplikasi 'by data'

\section{Product (Produk)}

Produk yang ditawarkan berupa jenis minuman es yang didesain dengan inovasi yang agak berbeda dengan jenis minuman lainnya. Minuman yang disajikan sesuai selera konsumen dengan berbagai macam varian rasa. Produk yang ditawarkan menggunakan kemasan yang menarik, dan praktis. Memiliki kekhasan tersendiri dalam menampilkan dan mengemas produk.

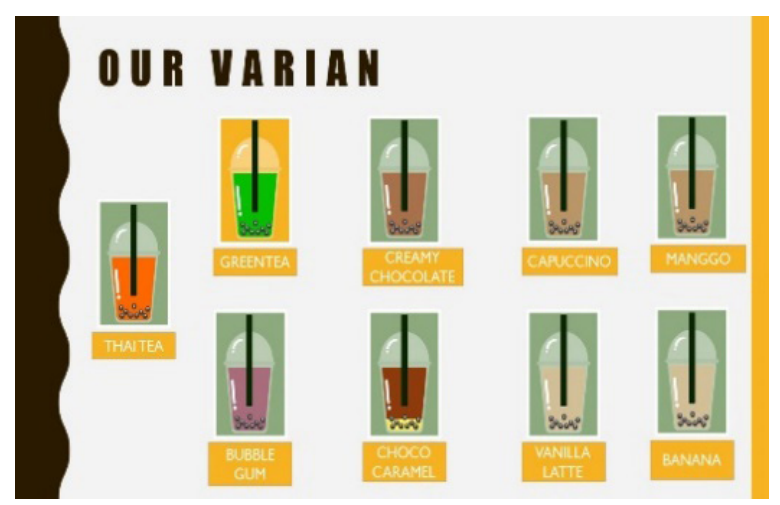

Gambar 2. Varian Rasa

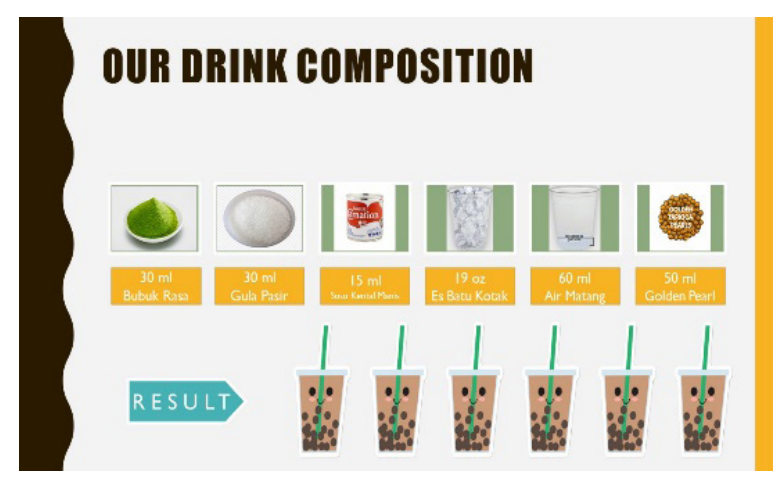

Gambar 3. Komposisi Minuman

\section{Price (Harga)}

Harga yang ditawarkan cukup terjangkau, sesuai dengan harga yang beredar di pasaran. Harga jual produk murah dan terjangkau unruk berbagai kalangan (cup besar 22 oz Rp.10.000; cup kecil 16 oz Rp.6000). Mampu bersaing harga dengan pesaing lainnya, usaha yang sejenis.

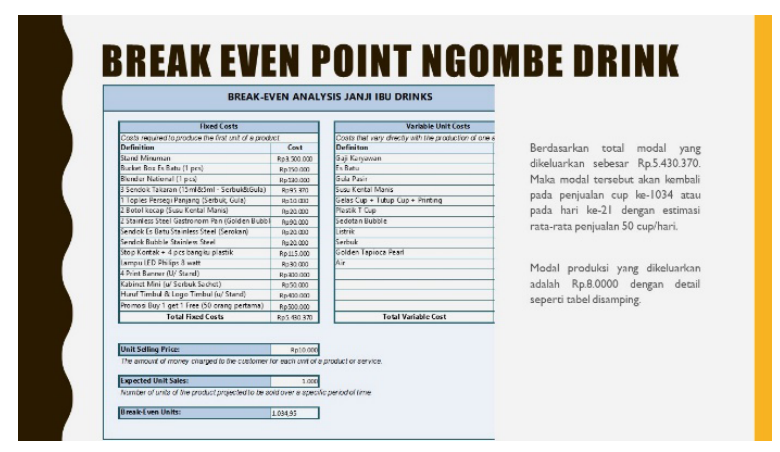

Gambar 4. Break Even Point (BEP) Minuman "NGOMBE"

\section{Place (Tempat)}

Tempat pemasaran adalah wilayah Indomaret dengan pertimbangan ramai pembeli. Lokasi yang stratefus, di depan halaman patkir Indomaret. Lokasi ramai pengunjung. Lokasi memudahlan konsumen, karena diuntungkan dengan posisi yang menjadi tempat belanja yakni minimarket (Indomaret).

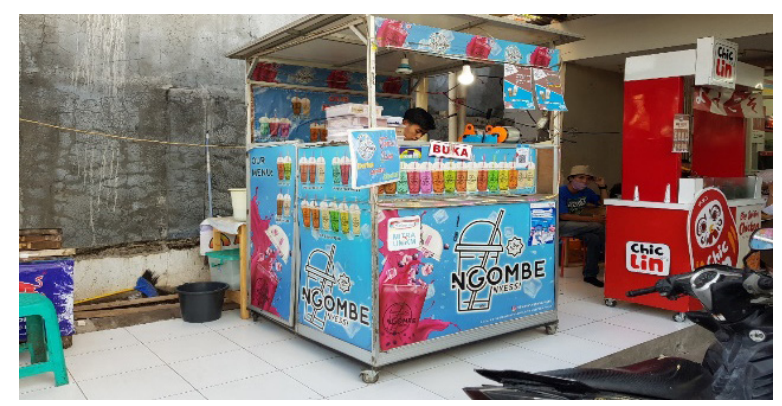

Gambar 5. Stand Minuman NGOMBE 


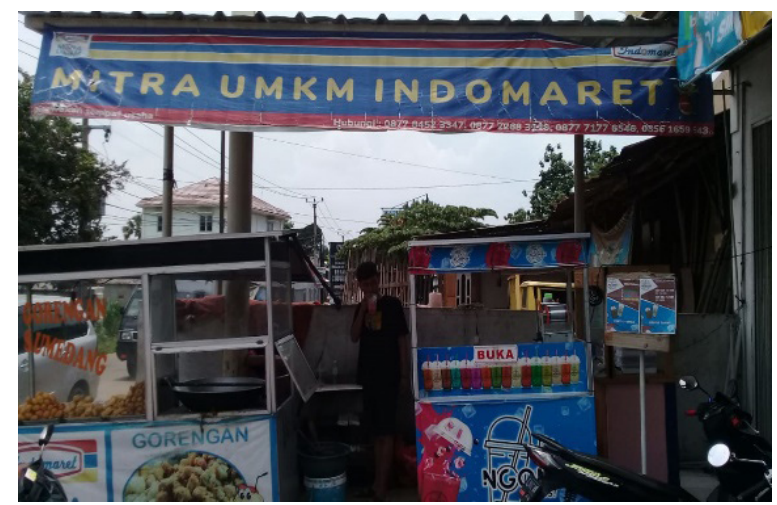

Gambar 6. Lokasi Stand

\section{Promotion (Promosi)}

Promosi usaha yang dilakukan dengan membuat brosur, media sosial, melalui internet atau jejaring sosial (Facebook, Instagram), Go Food dan Grab Food. Melakukan prtomosi harga, jika membeli 5 cup, gtatis 1 cup. Memberikan harga khusus di setiap event-event tertentu. Bekerja sama dengan Go Food dan Grab Food, ada harga khusus dan discount delivery.

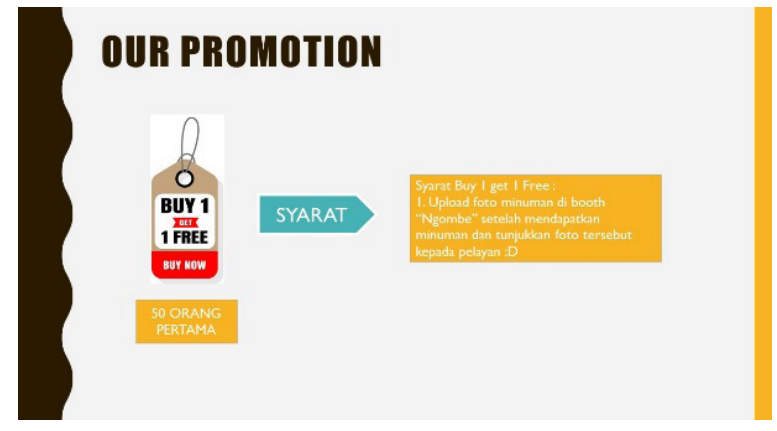

Gambar 7. Strategi Promosi 1

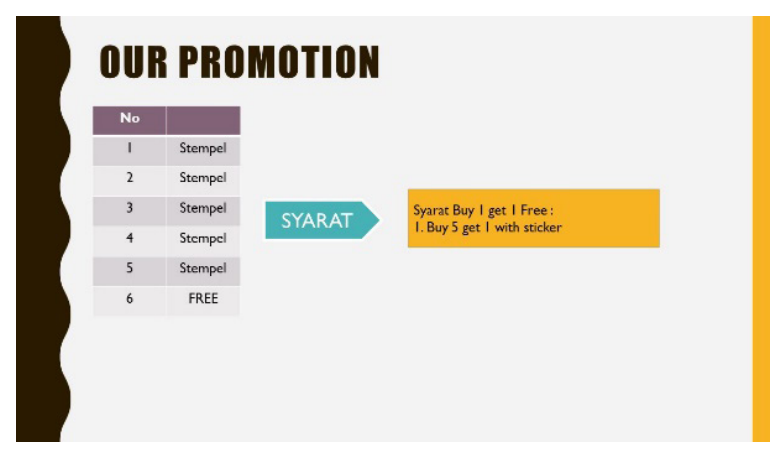

Gambar 8. Strategi Promosi 2

Sedangkan berdasarkan hasil Forum Group Discussion (FGD), didapatkan hasil penguatan yang dapat dilakukan kepada UKM minuman kekinian seperti memberikan pemahaman tentang 3 digital skill ditengah mewabahnya Covid-19. Melakukan sharing session antara pelaku usaha dengan konsumen dan stake houlder dengan keterbukaan hati dan pikiran untuk menciptakan Win-Win. Melakukan SWOT analys secara bersama untuk menentukan langkah strategis bagi usaha UKM minuman kekinian agar tetap eksis di semua kondisi atau keadaan.

Luaran yang dihasilkan dari masing-masing solusi di atas, berupa terbangunnya pemahaman tentang 3 digital skill yang harus dikuasai ditengah wabah Covid-19. Terbukanya hati dan pikiran antara pelaku usaha, konsumen dan mitra untuk menciptakan Win-Win dengan value yang berharga dan bermanfaat bagi semua. Dihasilkanya SWOT analisis usaha UKM minuman kekinian dan langkah strategis dalam bentuk Matrix SWOT.

\section{PEMBAHASAN}

Analisis SWOT

Faktor Internal

Kekuatan (Strength)

1) Produknya tidak akan surut oleh zaman

2) Diminati oleh berbagai kalangan konsumen

3) Mampu memberikan pelayanan secara langsung atau tidak langsung

4) Modal usaha cukup terjangkau

5) Lokasi usaha yang tidak terbatas

\section{Kelemahan (Weakness)}

1) Banyak usaha serupa yang menawarkan produk dengan harga yang lebih kompetitif

2) Sulit bersaing dengan usaha serupa yang sudah punya brand terkenal

a) Produk yang ditawarkan (rasa, kemasan, d1l)

b) Kecepatan pelayanan

c) Kepercayaan konsumen

d) Promo harga

e) Jangkauan konsumen yang terbatas

\section{Faktor Eksternal}

Peluang (Opportunity)

1) Mudah menjangkau dan meluaskan mitra usaha (franchise)

2) Mampu bertahan di tengah keadaan dan krisis ekonomi (biaya operasional lebih hemat)

3) Tetap menjadi trendsetter

4) Memberi peluang untuk tetap selalu berinovasi Ancaman (Treath) 
1) Bergesernya selera konsumen (Gaya hidup \& kecenderungannya)

2) Kondisi perekonomian yang tidak stabil (terutama di tengah situasi Pandemic Covid-19)

3) Kebijakan Pemerintah terutama dalam tarif Pajak (Tax) Usaha

4) Perkembangan dan kemajuan teknologi informasi

\section{Evaluasi Faktor Internal (EFI)}

Tabel 1 menunjukkan Matrik EFI (Kekuatan dan Kelemahan).

Tabel 1. Matrik EFI (Kekuatan dan Kelemahan)

\begin{tabular}{|c|c|c|c|c|}
\hline No & $\begin{array}{c}\text { STRENGTH (S)/ } \\
\text { Kekuatan }\end{array}$ & Bobot & Peringkat $_{\text {}}$ & $\begin{array}{c}\text { Nilai } \\
\text { Tertimbang }\end{array}$ \\
\hline 1 & $\begin{array}{l}\text { Produknya tidak } \\
\text { akan surut oleh } \\
\text { zaman }\end{array}$ & 0.10 & 2 & 0.20 \\
\hline 2 & $\begin{array}{l}\text { Diminati oleh } \\
\text { berbagai kalangan } \\
\text { konsumen }\end{array}$ & 0.15 & 3 & 0.45 \\
\hline 3 & $\begin{array}{l}\text { Mampu } \\
\text { memberikan } \\
\text { pelayanan secara } \\
\text { langsung atau } \\
\text { tidak langsung }\end{array}$ & 0.15 & 5 & 0.75 \\
\hline 4 & $\begin{array}{l}\text { Modal usaha } \\
\text { cukup terjangkau }\end{array}$ & 0.25 & 5 & 1.25 \\
\hline 5 & $\begin{array}{l}\text { Lokasi usaha } \\
\text { yang tidak } \\
\text { terbatas }\end{array}$ & 0.10 & 4 & 0.40 \\
\hline No & $\begin{array}{c}\text { WEAKNESS } \\
\text { (W)/Kelemahan }\end{array}$ & Bobot & Peringkat $_{7}$ & $\begin{array}{c}\text { Nilai } \\
\text { Tertimbang }\end{array}$ \\
\hline 1 & $\begin{array}{l}\text { Banyak usaha } \\
\text { serupa yang } \\
\text { menawarkan } \\
\text { produk dengan } \\
\text { harga yang lebih } \\
\text { kompetitif }\end{array}$ & 0.15 & 2 & 0.30 \\
\hline \multirow[t]{2}{*}{2} & $\begin{array}{l}\text { Sulit bersaing } \\
\text { dengan usaha } \\
\text { serupa yang sudah } \\
\text { punya brand } \\
\text { terkenal (produk, } \\
\text { kecepatan, } \\
\text { kepercayaan, } \\
\text { promo harga, } \\
\text { jangkauan } \\
\text { konsumen terbatas) }\end{array}$ & 0.10 & 3 & 0.30 \\
\hline & TOTAL & 1,00 & 24 & 3.65 \\
\hline
\end{tabular}

\section{Evaluasi Faktor Eksternal (EFE)}

Tabel 2 menunjukkan Matrik EFI (Peluang dan Ancaman).
Tabel 2. Matrik EFE (Peluang dan Ancaman)

\begin{tabular}{|c|c|c|c|c|}
\hline No & $\begin{array}{l}\text { OPPORTUNITY } \\
\text { (O) / Peluang }\end{array}$ & Bobot & Peringkat & $t_{\text {tertimbang }}$ Nilai \\
\hline 1 & $\begin{array}{l}\text { Mudah } \\
\text { menjangkau dan } \\
\text { meluaskan mitra } \\
\text { usaha (franchise) }\end{array}$ & 0.05 & 4 & 0.20 \\
\hline 2 & $\begin{array}{l}\text { Mampu bertahan } \\
\text { di tengah keadaan } \\
\text { dan krisis ekonomi } \\
\text { (biaya operasional } \\
\text { lebih hemat) }\end{array}$ & 0.10 & 4 & 0.40 \\
\hline 3 & $\begin{array}{l}\text { Tetap menjadi } \\
\text { trendsetter }\end{array}$ & 0.10 & 3 & 0.30 \\
\hline 4 & $\begin{array}{l}\text { Memberi peluang } \\
\text { untuk tetap selalu } \\
\text { berinovasi }\end{array}$ & 0.20 & 3 & 0.60 \\
\hline No & $\begin{array}{c}\text { TREATH }(\mathbf{W}) / \\
\text { Ancaman }\end{array}$ & Bobot & Peringkat & $\mathbf{t}_{\text {tertimbang }}$ Nilai \\
\hline 1 & $\begin{array}{l}\text { Bergesernya } \\
\text { selera konsumen } \\
\text { (Gaya hidup \& } \\
\text { kecenderungannya) }\end{array}$ & 0.20 & 4 & 0.80 \\
\hline 2 & $\begin{array}{l}\text { Kondisi } \\
\text { perekonomian } \\
\text { yang tidak stabil } \\
\text { (terutama di } \\
\text { tengah situasi } \\
\text { Pandemic } \\
\text { Covid-19) }\end{array}$ & 0.10 & 2 & 0.20 \\
\hline 3 & $\begin{array}{l}\text { Kebijakan } \\
\text { Pemerintah } \\
\text { terutama dalam } \\
\text { tarif Pajak (Tax) } \\
\text { Usaha }\end{array}$ & 0.10 & 2 & 0.20 \\
\hline \multirow[t]{2}{*}{4} & $\begin{array}{l}\text { Perkembangan } \\
\text { dan kemajuan } \\
\text { teknologi } \\
\text { informasi }\end{array}$ & 0.15 & 4 & 0.60 \\
\hline & TOTAL & 1 & 26 & 3.30 \\
\hline
\end{tabular}

\section{Keterangan:}

a. Bobot adalah pengaruh suatu faktor terhadap posisi strategis usaha. Bobot dari 1.0 (paling penting) sampai dengan 0.0 (tidak penting)

b. Rating/peringkat adalah respon pengusaha terhadap faktor-faktor tersebut. Nilai setiap faktor dari 5 (Sangat Baik) sampai dengan 1 (Sangat Tidak Baik)

Untuk menentukan Interpretasi Nilai EFI dan EFE maka dapat dihitung dengan menggunakan rumus:

Range $=($ Skor tertinggi - skor terendah $)$ : jumlah klasifikasi.

Range $=(5-1): 5=0,80$, sehingga dapat disusun tabel interpretasi EFI/EFE sebagai berikut: 


\section{Skor EFI/EFE}

$$
\begin{aligned}
& 4,20-5,50 \\
& 3,40-4,19 \\
& 2,60-3,39 \\
& 1,80-2,59 \\
& 1,00-1,79
\end{aligned}
$$

\section{Interpretasi}

Sangat Baik

Baik

Moderat/Cukup

Tidak Baik

Sangat Tidak Baik

Hasil perhitunganan EFI dan EFE diperoleh nilai skor tertimbang EFI sebesar 3.65, artinya usaha yang dikembangkan memiliki posisi kekuatan internal baik. Sedangkan skor tertimbang EFE diperoleh nilai 3,30 mengindikasikan bahwa faktor eksternal cukup mendukung usaha yang dilakukan.

\section{Analisis Matrik SPACE}

Matrik SPACE digunakan untuk mempetajam analisis SWOT usaha yang dilakukan sehingga dapat diketahui posisi dan perkembangan usaha selanjutnya.

\begin{tabular}{|c|c|c|c|}
\hline Kekuatan & Peringkat & Kelemahan & Peringkat \\
\hline $\begin{array}{l}\text { 1. Produknya } \\
\text { tidak akan } \\
\text { surut oleh } \\
\text { zaman }\end{array}$ & 2 & $\begin{array}{l}\text { 1. Banyak usaha } \\
\text { serupa yang } \\
\text { menawarkan } \\
\text { produk } \\
\text { dengan harga } \\
\text { yang lebih } \\
\text { kompetitif }\end{array}$ & 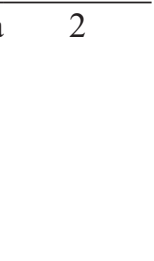 \\
\hline $\begin{array}{l}\text { 2. Diminati } \\
\text { oleh } \\
\text { berbagai } \\
\text { kalangan } \\
\text { konsumen }\end{array}$ & 3 & $\begin{array}{l}\text { 2. Sulit } \\
\text { bersaing } \\
\text { dengan } \\
\text { usaha serupa } \\
\text { yang sudah }\end{array}$ & 3 \\
\hline $\begin{array}{l}\text { 3. Mampu } \\
\text { memberikan } \\
\text { pelayanan } \\
\text { secara } \\
\text { langsung } \\
\text { atau tidak } \\
\text { langsung }\end{array}$ & 5 & $\begin{array}{l}\text { punya brand } \\
\text { terkenal } \\
\text { (produk, } \\
\text { kecepatan, } \\
\text { kepercayaan, } \\
\text { promo harga, } \\
\text { jangkauan }\end{array}$ & \\
\hline $\begin{array}{l}\text { 4. Modal } \\
\text { usaha cukup } \\
\text { terjangkau }\end{array}$ & 5 & $\begin{array}{l}\text { konsumen } \\
\text { terbatas) }\end{array}$ & \\
\hline $\begin{array}{l}\text { 5. Lokasi } \\
\text { usaha } \\
\text { yang tidak } \\
\text { terbatas }\end{array}$ & 4 & & \\
\hline Jumlah Total & 19 & Jumlah Total & 5 \\
\hline
\end{tabular}

Tabel 3 menunjukkan Matrik SPACE (Kekuatan dan Kelemahan).

Tabel 3. Matrik SPACE (Kekuatan dan Kelemahan)

\begin{tabular}{|c|c|c|c|}
\hline Peluang & Peringkat & Ancaman & Peringkat \\
\hline $\begin{array}{l}\text { 1. Mudah } \\
\text { menjangkau } \\
\text { dan } \\
\text { meluaskan } \\
\text { mitra usaha } \\
\text { (franchise) }\end{array}$ & 4 & $\begin{array}{l}\text { 1. Bergesernya } \\
\text { selera kon- } \\
\text { sumen (Gaya } \\
\text { hidup \& ke- } \\
\text { cenderungan- } \\
\text { nya) }\end{array}$ & 4 \\
\hline $\begin{array}{l}\text { 2. Mampu } \\
\text { bertahan } \\
\text { di tengah } \\
\text { keadaan } \\
\text { dan krisis } \\
\text { ekonomi } \\
\text { (biaya } \\
\text { operasional } \\
\text { lebih hemat) }\end{array}$ & 4 & $\begin{array}{l}\text { 2. Kondisi } \\
\text { perekonomian } \\
\text { yang tidak } \\
\text { stabil } \\
\text { (terutama di } \\
\text { tengah situasi } \\
\text { Pandemic } \\
\text { Covid-19) }\end{array}$ & 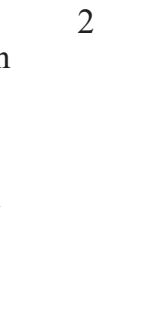 \\
\hline $\begin{array}{l}\text { 3. Tetap } \\
\text { menjadi } \\
\text { trendsetter }\end{array}$ & 3 & $\begin{array}{l}\text { 3. Kebijakan } \\
\text { Pemerintah } \\
\text { terutama } \\
\text { dalam tarif } \\
\text { Pajak (Tax) } \\
\text { Usaha }\end{array}$ & 2 \\
\hline $\begin{array}{l}\text { 4. Memberi } \\
\text { peluang } \\
\text { untuk tetap } \\
\text { selalu } \\
\text { berinovasi }\end{array}$ & 3 & $\begin{array}{l}\text { 4. Perkembangan } \\
\text { dan kemajuan } \\
\text { teknologi } \\
\text { informasi }\end{array}$ & n \\
\hline Jumlah Total & 14 & Jumlah Total & 12 \\
\hline
\end{tabular}

Tabel 4 menunjukkan Matrik SPACE (Peluang dan Ancaman).
Tabel 4. Matrik SPACE (Peluang dan Ancaman)

Tabel 5 menunjukkan Hasil Pengolahan Matrik SPACE.

Tabel 5. Hasil Pengolahan Matrik SPACE

\begin{tabular}{ll}
\hline Kekuatan $=19 / 5=3,6$ & Peluang $=14 / 4=3,5$ \\
Kelemahan $=-5 / 2=-2,5$ & Ancaman $=-12 / 4=-3,0$ \\
Kekuatan + Kelemahan & Peluang + Ancaman $=$ \\
$=3,6+(-2,5)=1,6$ & $3,5+(-3,0)=0,5$ \\
\hline
\end{tabular}

Berdasarkan peringkat pada matrik SPACE yang kemudian di ploting pada kuadran Space matrik diketahui posisi strategi perusahaan adalah Aggressive, seperti yang ada pada gambar berikut:

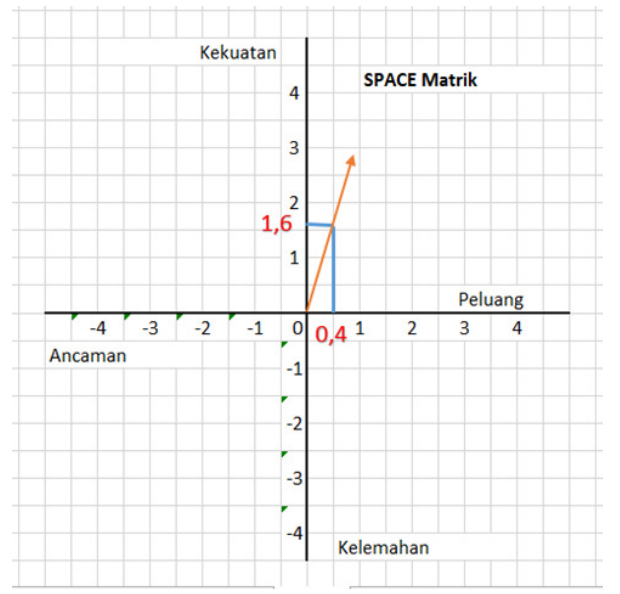

Gambar 9. Hasil Koordinat Pada Matrik SPACE 


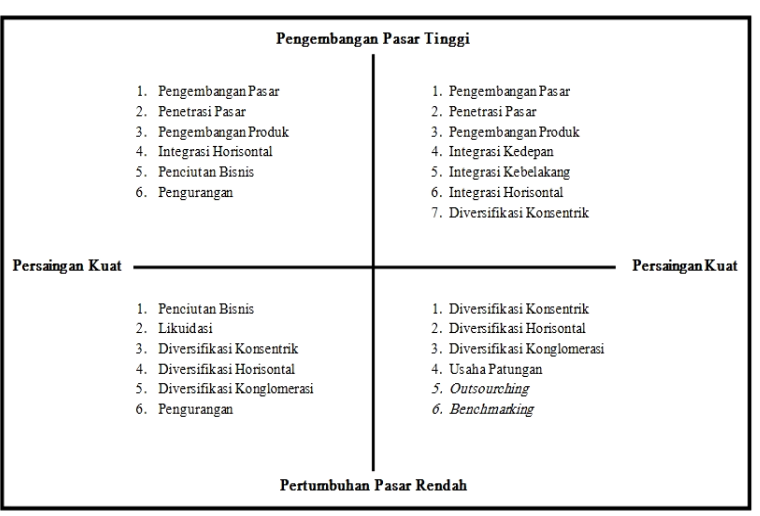

Gambar 10. Diagram Matrik Strategi Umum

Dengan menggunakan matrik SPACE, Usaha Minuman Ngombe berada pada posisi kuadran III yaitu kondisi agresif. Karenanya dalam melakukan pengembangan usahanya dapat memanfaatkan peluang yang ada dengan meminimalkan kelemahan.

Strategi yang digunakan yaitu mlakukan inovasi produk, baik dalam bentuk penampilan maupun rasa produk yang ditawarkan. Melakukan promosi secara optimal terutama di daerah Tangerang Selatan.

\section{Matrik SWOT}

Proses pencocokan dari identifikasi lingkungan internal dan lingkungan eksternal pada KJKS MBS menggunakan matrik SWOT dibagi menjadi empat tipe strategi di antaranya strategi SO, WO, ST dan WT.

Tabel 6 menunjukkan Analisis SWOT.

Tabel 6. Analisis SWOT

E F I STRENGIHT(S)
1.Produknya tidak akan surut oleh
zaman
2.Diminati oleh berbagai kalangan
konsumen
3. Mampu memberikan pelayanan
secara langsung atau tidak
langsung
4.Modal usaha cukup terjangkau
5.Lokasi usaha yang tidak terbatas

\section{E F I STIRENGIHT(S)}

1.Produknya tidak akan surut oleh zaman

2. Diminati oleh berbagai kalangan konsumen

3. Mampu memberikan pelayanan secara langsung atau tidak langsung

E F E

4. Modal usaha cukup terjangkau

5. Lokasi usaha yang tidak terbatas

\section{OPPORIUNIMYT(O)}

1. Mudah menjangkau dan meluaskan mitra usaha (franchise)

2. Mampu bertahan di tengah keadaan dan krisis ekonomi (biaya operasional lebih hemat)

3. Tetap menjadi trendsetter

4. Memberi peluang untuk tetap selalu berinovasi

\section{IREAMHA (T)}

1. Bergesernya selera konsumen (Gaya hidup \& kecenderungannya)

2. Kondisi perekonomian yang tidak stabil (terutama di tengah situasi Pandemic Covid-19)

3. Kebijakan Pemerintah terutama dalam tarif Pajak (Tax) Usaha

4. Perkembangan dan kemajuan teknologi informasi

\section{STIRATIEGI S-O}

1. Memberikan peluang usaha bagi pelaku usaha baru (franchise)

2. Tetap menjaga original dan kualitas produk

3. Inovasi usaha dalam hal produk, teknologi informasi, pemasaran dan promosi

\section{STRAYIEGIS-I}

1. Tetap mempelajari perkembangan dan perubahan selera pasar (konsumen) agar tidak tergerus oleh zaman

2. Menjaga semua potensi yang sudah dimiliki (SDM, strategi bisnis internal, relasi bisnis)

3. Tetap mengikuti perkembangan teknologi informasi untuk menunjang inovasi produk, pelayanan dan penjualan

\section{WEAKNESS (S)}

1. Banyak usaha serupa yang menawarkan produk dengan harga yang lebih kompetitif

2. Sulit bersaing dengan usaha serupa yang sudah punya brand terkenal

- Produk yang ditawarkan (rasa, kemasan, dil)

- Kecepatan pelayanan

- Kepercayaan konsumen

- Promo harga

- Jangkauan konsumen yang terbatas

\section{WEAKNESS (S)}

1. Banyak usaha serupa yang menawarkan produk dengan harga yang lebih kompetitif

2. Sulit bersaing dengan usaha serupa yang sudah punya brand terkenal

- Produk yang ditawarkan (rasa, kemasan, dil)

- Kecepatan pelayanan

- Kepercayaan konsumen

- Promo harga

- Jangkauan konsumen yang terbatas

\section{STIRAYIEGT W-O}

1. Buka Outlet atau Booth di tempat ramai

2. Kemasan kekinian menarik pelanggan

3. Sering mengadakan promosi

4. Rajin ikut Bazar dan Event

5. Aktif Sosial Media

\section{STIRAYUEGIN-1}

1. Mengawali usaha dari rumah untuk menghemat biaya operasional

2. Melangkah dengan bimbingan Mentor

3. Menjalin kerjasama dengan Mitra terkait

4. Sering mengikuti Pelatihan atau Workshop Inovasi Usaha 
Berdasarkan hasil pengamatan peneliti melalui semua langkah-langkah yang sesuai dengan rumusan masalah, kajian Pustaka, dan mengikuti tahapan-tahapan penelitian, maka dapat digambarkan bahwa sistem aplikasi by data merupakan sutu inovasi usaha yang dapat mendukung jalannya usaha minuman kekinin "NGOMBE" dalam hal peningkatan penjualan dan kemudahan layanan kepada konsumen.

Sistem aplikasi 'by data' dapat membantu para pelaku usaha minuman kekinian dalam mengembangkan usahanya sehingga tercapai peningkatan penjualan yang cukup signifikan dan memberi keuntungan secara ekonomis. Dengan mengikuti pengembangan produk (merk/brand, varian rasa, pengemasan, dan pemasaran), produk minuman akan mampu bersaing dengan kompetitor minuman sejenis. Apalagi didukung dengan penggunaan sistem aplikasi 'by data' dalam menunjang pengontrolan penjualan, berdampak kepada peningkatan penjualan dan kemudahan dalam pelayanan kepada konsumen

\section{SIMPULAN}

Berdasarkan hasil analisa dapat disimpulkan beberapa hal; bahwa usaha minuman kekinian masih akan menjadi trend usaha yang menjanjikan di tengah iklim ekonomi yang masih krisis ini; yakni menggunakan modal kecil namun memberikan keuntungan yang menjanjikan. Usaha mjnuman kekinian yang menggunakan system aplikasi IT akan memudahkan dalam penjualan dan pembelian. Lebih lanjut lagi bahwa sistem aplikasi 'by data' memberikan kemudahan dalam penjualan dan pembelian; juga memberikan keuntungan yang signifikan bagi pemiliknya.

\section{PENGHARGAAN}

Ucapan terima kasih disampaikan Kemenristek Dikti/BRIN yang telah memberikan dana hibah dan serta membimbing dan mengarahkan hingga terlaksananya penelitian ini dari awal sampai akhir. Selanjutnya kepada Dr. Ali Maddinsyah S.E., M.M, selaku Ketua LPPM (Lembaga Penelitian dan Pengabdian kepada Masyarakat) Universitas Pamulang, atas waktu, sumbangan pemikiran, dan bimbingannya dari awal hingga akhir pelaksanaan penelitian ini. Selain itu juga kepada narasumber dan objek penelitian, Joko Susilo, (Pemilik Usaha Minuman "NGOMBE") yang telah banyak membantu memberikan informasi dan berbagi pengalaman sehingga selesainya penelitian ini.
Serta, keluarga, teman-teman dosen dan pihakpihak terkait yang juga membantu dan mendukung terlaksananya kegiatan penelitian ini.

\section{DAFTAR PUSTAKA}

Al Rasyid, H. (2018, Maret). Pengaruh Inovasi Produk Terhadap Keputusan Pembelian Motor Yamaha di Kota Tangerang Selatan. Jurnal Perspektif, XVI(1), 39-49.

Ananda, A. D., Ananda, A. D., \& Susilowati, D. (2017). Pengembangan Usaha Mikro Kecil Dan Menengah (Umkm) Berbasis Industri Kreatif Di Kota Malang. Jurnal Ilmu Ekonomi,X(10), 120-142.

Asashi, T. \& Sukaatmaja., I.P.G. (2017). Peran Inovasi Produk dalam Memediasi Pengaruh Orientasi Pasar Terhadap Kinerja Pemasaran. E-Jurnal Manajemen Unud, VI(4), 1816-1845.

Curatman, A. (2016, Desember). Analisis Faktorfaktor Pengaruh Inovasi Produk yang Berdampak pada Keunggulan Bersaing UKM Makanan dan Minuman di Wolayah Harjamukti Lota Cirebon Minuman. Jurnal Logika, XVIII(3), 61-75.

Defrina D., \& Leatari D.P. (2017). Aplikasi Pemesanan Makanan dan Minuman Online Berbasis Mobile Browser pada Restoran Tiga Saudara. Jurnal Inovasi Produk, , XXII (3), 158-170

Ekasari, N. (2017, 12). Pengaruh Inovasi Produk terhadap Keputusan Pembelian Konsumen Bisnis pada UMK Keripik Pisang Dharma Jaya. Jurnal Manajemen Terapan dan Keuangan,VI (3), 195-207.

Firmansyah, M.A.(2017). Globalisasi Pemasaran. Yogyakarta: DeePublish Group CV Budi Utama.

Gaol, J. C. (2015). A to Z Human Capital Manajemen Sumber Daya Manusia. Jakarta: GRASINDO.

Hadiyati, E. (2011, Maret). Kreativitas dan Inovasi Berpengaruh terhadap Kewirausahaan Usaha Kecil. Jurnal Manajemen dan Kewirausahaan, XIII(1), 8-16.

Hasibuan, M. S. (2016). Manajemen Dasar, Pengertian dan Masalah (Vol. XII). Jakarta: PT Bumi Aksara.

Hussein, A. S. (2018). Metode Design Thinking untuk Inovasi Bisnis. Malang: Tim UB Press.

Kotler,P.,.\&Amstrong, G.DasarDasarPemasaran. (2012). (A. Sundoro, Trans.) Jakarta: Indeks.

Mulyadi, W. dkk. (2016). Pengaruh Inovasi, Kreativitas, dan Kepuasan Konsumen terhadap Keunggulam Kompetitif Sebuah Studi kasus. Ptrosiding Seminar Nasional dan Teknologi Informasi, (pp. 5-6). 
Nasir, A. (2017, Desember). Pengaruh Inovasi Produk terhadap Kinerja Pemasaran Industri Mebel di Kabupatem Pasuruan. Jurnal Ilmu Manajemen dan Akuntansi, V(1), 20-25.

Nugraha, R., dkk. (2014). Usulan peningkatan pelayanan jasa bengkel " $X$ " berdasarkan hasil matriks importance performance analysis, (Studi Kasus di Bengkel Motor AHASS PD Sumber Motor Karawang),. Jurnal Online Institut Teknologi Nasional, I (3), 221-231.

Pattipeiloliy, V. R. (2018, Juni). Inovasi Ptoduk dan Keunggulan Bersaing pengaruhnya terhadap Kinerja Pemasaran (Studi pada Usaha Nasi Kuning di Kelutahan Batu Meja Lota Ambon). Jurnal Maneksi, VII(1), 66-73.

Purwana, D., dkk. (2017, Maret). Pengaruh Pelatihan dan Kreativitas terhadap pengembangan usaha pada Usaha Kecil dan Menengah di perkampungan Industri Kecil Pulo Gadung Jakarta Timur. Jurnal Ilmiah Econosains, XV(1), 72-86.

Rivai, V. (2013). Manajemen Sumber Daya Manusia untuk Perusahaan (Vol. V). Depok: PT Raja Grafindo Persada.

Setiawan, H. (2012). Pengaruh Orientasi Pasar, Orientasi Teknologi dan Inovasi Produk terhadap Keunggulan Bersaing Usaha Songket
Skala Kecil di Kota Palembang. Jurnal Orasi Bisnis, VIII, 12-19.

Sugiyono. (2011). Metode Penelitian Kuantitatif Kualitatif dan $R \& D$. . Bandung: Alfabeta.

Sunyoto, D. (2014). Dasar Dasar Manajemen Pemasaran Konsep, Strategi, dan Kasus (Vol. III). Jakarta: CAPS (Center of Academic Publishing Service).

Suparyanto, R. (2014). Pengantar Bisnis Konsep, Realita dan Aplikasi pada Usaha Kecil. Tangerang : PT Pustaka Mandiri.

Suprapti, A. R., dkk. (2016, Desember). Inovasi Design, Teknologi dan Pemasaran lewat Website Usaha Kecil dan Menengah Batik dan Lurik (Lurik Batik) di Kecamatan Laweyan Surakarta. Jurnal Ekonomi dan Bisnis, XIX(3), 397-412.

Taman, P., dkk. (2020). Pengaruh Inovasi Produk dan Brand Awareness terhadap Keputusan Pembelian Konsumen pada PT Unilever Indonesia. Jurnal Inovasi Ilmiah Manajemen Universitas Pamulang, VII(1), 24-31.

Wijayanto, D. (2012). Pengantar Manajemen. Jakarta: PT Gramedia Pustaka Utama. 